\title{
Effect of Storage and Packaging on the Quality of Dehydrated and Dehydrofrozen Pigeonpeas
}

\author{
Abdul R. Rahman ${ }^{1}$
}

\section{INTRODUCTION}

Dehydrated foods, even though heat-treated, possess very low moisture, and may be hermetically sealed but undergo changes in both organoleptic quality and nutritive value in storage. These may result from reactions within the food, from interactions between food and containers, or from surface reactions stimulated by light passing through the container wall. Although the nature of such changes varies considerably with the type of product and method of processing and packaging, they are largely determined by the temperature at which the food is stored.

\section{REVIEW OF THE LITERATURE}

Cecil and Woodroof $(1)^{2}$ indicated that storage at $100^{\circ} \mathrm{F}$. resulted in some types of color changes within a few weeks in 35 types of canned products used in civilian and military supplies, such as vegetable products, cheese, and meat. However, less pronounced changes occurred more slowly at $70^{\circ} \mathrm{F}$. Molaison et al. (2) reported that dehydrated sweetpotato dice have storage stability of at least 12 months at $100^{\circ} \mathrm{F}$., for preference declined only very slightly under such storage. Jones and Gersdorff $(ß)$ pointed out the possible significance of changes in the nutritive value of cereals and soybean upon storage, and demonstrated by in vitro tests that the solubility of the protein in salt solution and the enzyme digestibility decreased during storage.

Masure (4) reported that the storage life of diced dehydrated carrots at $84^{\circ} \mathrm{F}$., sealed in cellophane, was increased four- to sixfold and the quality was retained for 9 months by a coating of hot 2 to 5 percent of corn starch sprayed on the hot blanched dice before drying. Packing in well-filled hermetically sealed cans increased the $84^{\circ} \mathrm{F}$. storage life of blanched and blanched sulfited samples by only few weeks. However, packing the blanched or the blanched and sulfited product in well-filled hermetically sealed cans increased the $84^{\circ} \mathrm{F}$. storage life by approximately 100 percent

1 Food Technologist, Food Technolugy Laboratory, Agricultural Experiment Station, University of Puerto Rico, Río Piedras, P.R. The author wishes to express his appreciation and gratitude to the members of the staff of the Food Technology Laboratory, who assisted in the chemical analyses or the organoleptic evaluation of the pigeonpeas during the course of this study. Special acknowledgment is due the staff of the Central Analytical Laboratory for their assistance in the protein analyses of the dehydrated and dehydrofrozen pigeonpeas.

2 Italic numbers in parentheses refer to Literature Cited, p. 326. 
over packing in cellophane. Cruess and Pancoast (5) reported on dried apricots containing 2,700 p.p.m. of $\mathrm{SO}_{2}$ in hermetically sealed jars and stored samples at $32^{\circ} \mathrm{F}$., room temperature $\left(70^{\circ} \mathrm{F}\right.$.), and $115^{\circ} \mathrm{F}$. Within 3 weeks at $115^{\circ} \mathrm{F}$. the fruit had darkened considerably; at room temperature, darkening did not occur until after 3 months.

Talburt and Legalt $(6)$ stated that dehydrofrozen peas, when partly dried to reduce weight and volume by about 50 percent, were equal in quality to frozen peas both immediately after processing and after 1 year of storage at $-10^{\circ} \mathrm{F}$. Rahman ( 7$)$ concluded that dehydrated pigeonpeas which were soaked for 4 hours in a 0.2-percent solution of sodium hydroxide before dehydration possessed better quality than the untreated ones. Lambou (8) found that storage of dehydrated dices of sweetpotatoes under nitrogen in cans stored at $-10,75^{\circ}$, and $100^{\circ} \mathrm{F}$. for periods ranging from 9 to 27 weeks had little or no effect on the palatability of the reconstituted dice. Dutton et al. (9) stated that the destruction of chlorophyll is accelerated by increased moisture content and is little affected by storage in an atmosphere of oxygen, air, carbon dioxide, or nitrogen; the rate of carotene destruction is accelerated by oxygen in the storage atmosphere and is unaffected by moisture content. Gooding and Duckworth (12) have demonstrated that changes in the culinary properties, color, flavor, and texture of dehydrated vegetables occurring during storage for 1 month at $37^{\circ} \mathrm{C}$. can be reproduced in 1 day at $55^{\circ} \mathrm{C}$.

\section{PROCEDURE}

Pigeonpeas (Cajan cajan $\mathrm{L}$ ) of the variety Kaki, with a moisture content of 73.83 percent, were cleaned and then blanched at $190^{\circ} \mathrm{F}$. for 5 minutes in the pilot plant of the Food Technology Laboratory of the Agricultural Experiment Station.

Five equal lots of pigeonpeas were used in this study. Four lots were soaked in a 0.2-percent solution of sodium hydroxide for 4 hours. Immediately after soaking, the pigeonpeas were thoroughly drained and washed. Each of the five lots was placed in perforated trays $30 \times 20 \times 2$ inches in size.

\section{EHYDRATION}

The procedure of dehydration of pigeonpeas developed by Rahman (7) was applied in the course of this study. The trays were placed in the Proctor and Schwartz cabinet dehydrator at the same time. The dry-bulb temperature was set at $200^{\circ} \mathrm{F}$., using the cross-circulation airflow and after 1 hour it was reduced to $150^{\circ} \mathrm{F}$. for the rest of the dehydration time which was 3 hours. However, one of the lots was taken out of the dehydrator as soon as the weight was reduced to about 50 percent. The semidry pigeonpeas of 
this lot were placed in polyethylene bags, frozen, and then stored at $-10^{\circ} \mathrm{F}$. The other four lots were given the full dehydration cycle. Two lots were packed in polyethylene bags where one lot was stored at room temperature and the other at $100^{\circ} \mathrm{F}$. The other two lots were packed in No. 10 tin cans; one lot was stored at room temperature and the other at $100^{\circ} \mathrm{F}$. The storage period for all the lots was 1 year.

The reconstitution was conducted by adding $250 \mathrm{ml}$. of water to each 100 gm. of dehydrated pigeonpeas and heating until boiling and then the mixture was allowed to simmer for 1 hour. The pigeonpeas were then drained and weighed.

\section{ORGANOLEPTIC APPRAISALS}

Dehydrated, as well as dehydrofrozen pigeonpeas, were cooked either with rice or as stew (guisado) applying the same methods used locally by housewives. Samples representing each lot were appraised by an experienced panel using the Hedonic scale (10) as an indication of the degree of acceptance. In this method a scale ranging from "like extremely," which indicated a rating of 9 points to "dislike extremely" rated 1 point. The samples were served in coded small plates to the judges seated in individual air-conditioned tasting booths. Amber light was used to mask small differences in color between the samples of pigeonpeas while judging the flavor. The color of the reconstituted pigeonpeas was scored under daylight before and after cooking.

The texture of the reconstituted pigeonpeas was determined by means of the shear-press. The color was determined by the Hunter color and colordifference meter. Spectrophotometric measurements of the liquids obtained from the reconstitution of dehydrated pigeonpeas were conducted by the Beckman Model DU spectrophotometer.

\section{CHEMICAL ANALYSES}

The moisture content of the pigeonpeas was determined by means of drying in the vacuum oven. The protein was determined by the Kjedahl method. The starch, total sugars, and reducing sugars were determined by the A.O.A.C. methods (11). All the analyses were made in duplicate and then averaged.

\section{RESULTS AND DISCUSSION}

\section{CHEMICAL ANALYSES}

The results of the chemical analyses indicated in table 1 show that pigeonpeas stored in polyethylene bags at room temperature, as well as at $100^{\circ} \mathrm{F}$., contained less total sugars than the rest of the samples. However, no 
noticeable difference was shown between the samples regarding reducing sugars, proteins, and starch.

The highest percentage of reconstitution obtained was that of the dehydrofrozen samples whereas the lowest was that of those packed in polyethylene bags and stored at $100^{\circ} \mathrm{F}$. However, pigeonpeas stored in cans at $100^{\circ} \mathrm{F}$., as well as in polyethylene bags, at room temperature, showed a

TАВLе 1.-Chemical analyses (percenlage) of rehydrated pigeonpeas after 1 year of storage

\begin{tabular}{l|r|r|r|r|r}
\hline \multicolumn{1}{c|}{ Constituent } & \multicolumn{2}{|c|}{ Results of temperature of storage and in type of packaging } \\
indicated
\end{tabular}

TABLE 2.-Values of the shear-press and Hunter color and color-difference meler for the rehydrated pigeonpeas after 1 year of storage

\begin{tabular}{c|c|c|c|c|c}
\hline & \multicolumn{3}{|c|}{ Results at temperature of storage and in type of packaging } \\
indicated
\end{tabular}

lower percentage of reconstitution than those stored in cans at room temperature. This might be the result of a higher temperature of storage, which could cause denaturation of the proteins, and also, to some oxidation processes occurring because of the presence of oxygen in the polyethylene bags.

\section{OBJECTIVE TESTS FOR COLOR AND TEXTURE}

The results from use of the shear-press shown in table 2 indicate that the tenderest sample was the dehydrofrozen and the toughest was the one 
stored in polyethylene bags at $100^{\circ} \mathrm{F}$. However, the samples stored in cans were more tender than those stored in polyethylene bags, regardless of the temperature. The dehydrofrozen pigeonpeas had the best color, followed by those packed in cans, and stored at room temperature, and at $100^{\circ} \mathrm{F}$., respectively. Whereas pigeonpeas stored in polyethylene bags at room

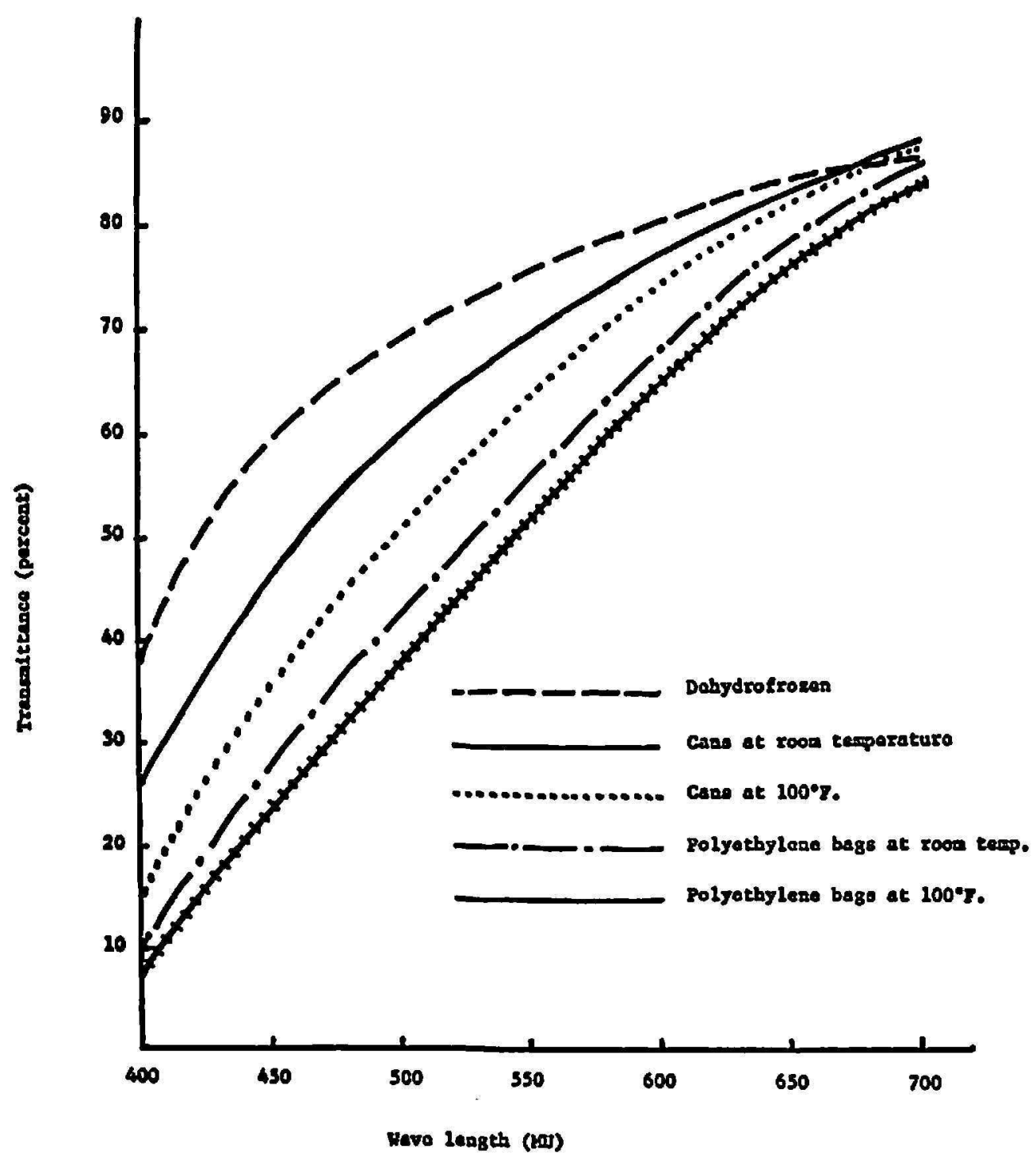

FIG. 1.-Spectral transmittance (Beckman J)U Spectrophotometer) of solutions obtained by the reconstitution of dehydrated pigeonpeas, as affected by storage and packaging.

temperature, as well as at $100^{\circ} \mathrm{F}$., had the poorest color because of the development of browning, which was more intensive in those stored at $100^{\circ} \mathrm{F}$., as indicated in table 2 and figures 1 and 2.

\section{ORGANOLEPTIC APPRAISALS}

The results shown in table 3 indicate that, after 6 months of storage, the mean scores of the flavor of dehydrofrozen pigeonpeas cooked with rice was 
significantly higher than that of those stored in polyethylene bags at both temperatures. However, the judges scored the samples stored in cans at both temperatures somewhat higher than those stored in polyethylene bags, regardless of the temperature, yet no significant difference could be established. After 1 year of storage, the judges scored the color of dehydrofrozen pigeonpeas upon reconstitution (before cooking) the highest, and a significant difference was established when compared with those stored in
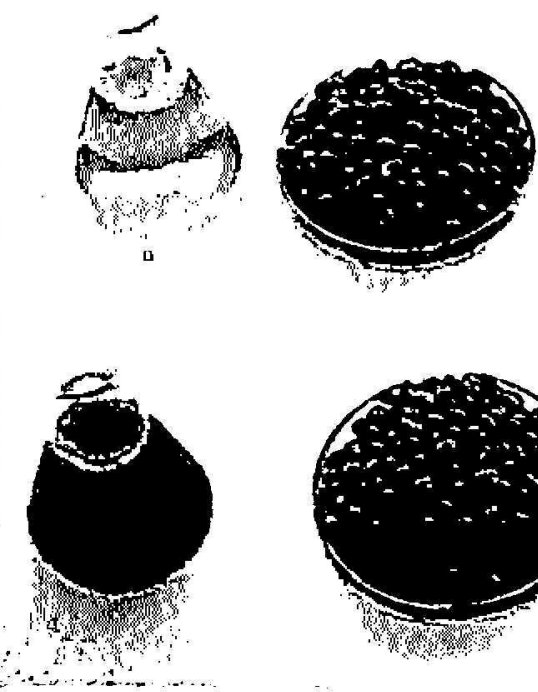
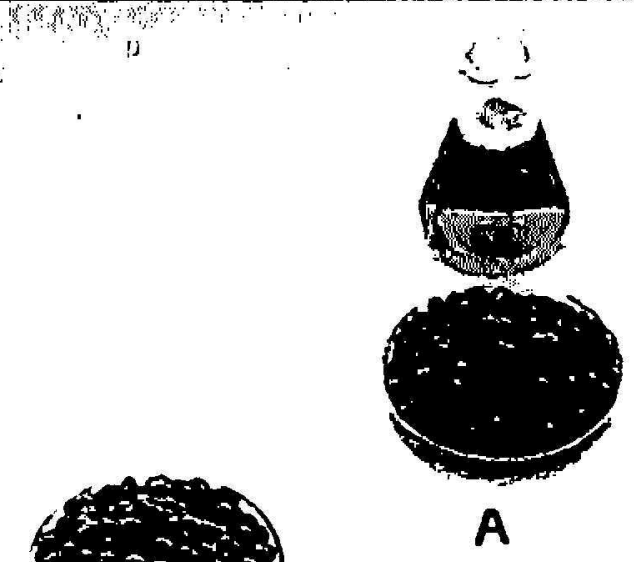

$\mathbf{E}$

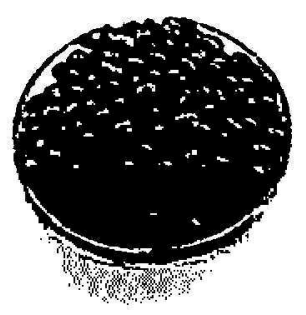

B
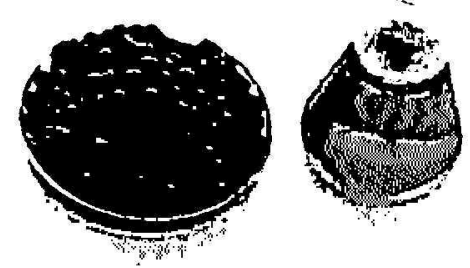

D
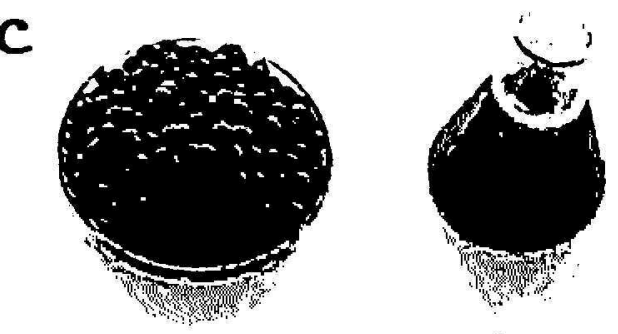

Fra. 2.-Color of solutions obtained by the reconstitution of deliydrated pigeonpeas as affected by storage and packaging: A, Cans at $100^{\circ} \mathrm{F}$; $\mathrm{B}$, cans at room temperature; $C$, polyethylene bags at room temperature; 1), polyethylene bags at $100^{\circ} \mathrm{F}$.; is, dehydrofrozen.

polyethylene bags at both temperatures. However, although dehydrofrozen pigeonpeas had a higher score than those stored in cans at both temperatures, yet no significant difference could be established. The flavor as well as the color of dehydrofrozen pigeonpeas attained higher scores than the rest of the samples. However, a significant difference could be established only upon comparing the color of dehydrofrozen pigeonpeas with those stored in polyethylene bags at $100^{\circ} \%$.

No significant difference could be established between the flavor of the various pigeonpeas when cooked as stew, although the dehydrofrozen, as well as those stored in eans, received somewhat higher scores than those 
stored in polyethylene bags. However, the color of dehydrofrozen pigeonpeas, as well as of those stored in cans at room temperature, was significantly higher than those stored in polyethylene bags at both temperatures.

T.ІвL.E 3.-The arerage of the scores of 10 judges, indicating the degree of acceptance of the color and flaror of cooked dehydrated pigeonpeas as affected by packaging and storage

\begin{tabular}{l|c|c|c|c|c} 
Organoleptic appraisals of pigeonpeas & Results at temperature of storage and in type of packaging \\
indicated
\end{tabular}

L.'.'.1). at 5-percent level $=1.08$

\begin{tabular}{l|l|l|l|l|l}
$\begin{array}{c}\text { Color of recomstituted pigeonpens } \\
\text { after } 1 \text { year }\end{array}$ & 5.1 & +.9 & 6.1 & 5.5 & 7.6 \\
\hline
\end{tabular}

L.S.D. at 5-pereent level $=2.44$

\begin{tabular}{l|l|l|l|l|l}
\hline $\begin{array}{c}\text { Flavor of pigeonpeas cooked with } \\
\text { rice after 1 year }\end{array}$ & 7.2 & 7.0 & 7.8 & 7.7 & 7.9 \\
\hline
\end{tabular}

L.S.I). at 5-pereent level $=1.10$

\begin{tabular}{l|l|l|l|l|l}
\hline $\begin{array}{c}\text { Color of pigeonpeas cooked with } \\
\text { rice after 1 year }\end{array}$ & 7.2 & 6.3 & 7.8 & 7.8 & 8.0 \\
\hline
\end{tabular}

L.S.1). at 5-percent level $=1.50$

\begin{tabular}{ll|l|l|l|l}
$\begin{array}{c}\text { Flavor of pigeonpeus cooked as } \\
\text { stew (ymisado) after 1 year }\end{array}$ & 6.6 & 6.9 & 7.6 & 7.6 & 7.5 \\
\hline
\end{tabular}

I..S.I). at 5-pereent level $=1.23$

\begin{tabular}{|c|c|c|c|c|c|}
\hline $\begin{array}{l}\text { Color of pigcompeas cooked as } \\
\text { stew (guisado) after } 1 \text { year }\end{array}$ & 0.5 & li.ti & 7.9 & 7.0 & 7.9 \\
\hline
\end{tabular}

L..i.1). at 5-pereent level $=1.23$

It is concluded that, although pigeonpeas stored for 1 year in polyethylene bags at room temperature, as well as at $100^{\circ} \mathrm{F}$., received somewhat lower scores in flavor and color than the others, they yet possessed fairly good (fuality, and received a considerable degree of acceptance from the tasting 
panel. This indicates that it might be more advantageous economically to pack the dehydrated pigeonpeas in polyethylene bags instead of tin cans.

\section{SUMMARY}

A study was undertaken to determine the effects of type of packaging and temperature of storage on the quality of dehydrated and dehydrofrozen pigeonpeas. Green pigeonpeas were soaked in 0.2-percent solution of sodium hydroxide for 4 hours and then dehydrated. The dehydrated pigeonpeas were packed in polyethylene bags and in tin cans, and stored for 1 year at room temperature, as well as at $100^{\circ} \mathrm{F}$. Dehydrofrozen pigeonpeas were packed in polyethylene bags and stored at $-10^{\circ} \mathrm{F}$. The results follow.

1. Pigeonpeas packed in polyethylene bags had the lowest total sugars, regardless of the temperature of storage, whereas no noticeable difference in the contents of starch, protein, and reducing sugars was obtained between the different samples.

2. The dehydrofrozen pigeonpeas had the best color. Color deterioration occurred in other samples in the following order: Pigeonpeas in cans stored at room temperature had the best color, in cans at $100^{\circ} \mathrm{F}$. the next best, in polyethylene bags at room temperature came next, and in polyethylene bags at $100^{\circ} \mathrm{F}$. the poorest color.

3. The dehydrofrozen pigeonpeas, as well as those stored in cans, had better texture (i.e. were more tender) than those stored in polyethylene bags at both temperatures.

4. The organoleptic appraisals indicated that the dehydrofrozen pigeonpeas received somewhat higher scores than the others, followed by those stored in tin cans and in polyethylene bags, respectively. However, the palatability of the pigeonpeas packed in polyethylene bags was not greatly affected, and they received a considerable degree of acceptance from the judges.

\section{RIESUMEN}

Se llevó a cabo un estudio para determinar el efecto del tipo de envase y la temperatura de almacenamiento en la calidad del gandur deshidratado y el gandur deshidratado y congelado (dehydrofrozen). El grano se sometió a un tratamiento de inmersión en hidróxido de sodio al 2 por ciento, por cuatro horas, antes de deshidratar. El gandur deshidratado se envasó en bolsas de polietileno y en latas estañadas y se almacenó por un año a temperatura ambiente y también a temperatura de $100^{\circ} \mathrm{F}$. El gandur deshidratado y congelado se envasó en bolsas de polietileno y sc almacenó a $10^{\circ} \mathrm{F}$. Se obtuvieron los siguientes resultados:

1. El gandur envasado en bolsas de polietileno tiene el menor contenido de azúcares totales sin que importe la temperatura de almacenamiento, 
pero su contenido de almidón, proteínas y azúcares reductoras no varió en forma apreciable en las distintas muestras.

2. Los gandures deshidratados y congelados poseían el mejor color. En las otras muestras el deterioro del color ocurrió en el siguiente orden: Gandures en latas a temperatura de ambiente, en latas a $100^{\circ} \mathrm{F}$., en bolsas de polietileno a $100^{\circ} \mathrm{F}$., que fue la muestra de color más pobre.

3. Los gandures deshidratados y congelados, y también los envasados en latas, poseen mejor textura (más tiernos) que los envasados en bolsas de polietileno y almacenados a las dos temperaturas.

4. Las pruebas organolépticas indicaron que el gandur deshidratado y congelado fue mejor catalogado que los otros, seguido por los que fueron envasados en latas y por los que fueron envasados en bolsas de polietileno, respectivamente. Sin embargo, el gandur envasado en bolsas de polietileno, fue aceptado por los catadores y clasificado como un producto aceptable.

\section{LITERATURE CITED}

1. Cecil, S. R., and Woodroof, J. A., The stability of canned foods in long-term storage, Food Technol. 17 (5) 131-41, 1963.

2. Molaison, L. J., Spadaro, J. J., Roby, M. T., and Frances, H. L., Dehydrated diced sweetpotatoes-A pilot-plant process and product evaluation, Food Technol., 16 (11), 101-4, 1962.

3. Jones, D. B., and Gersdorff, C. E. F., Changes that occur in the protein of soybean meal as a result of storage, $J$. Am. Chem. Soc. $60723-4,1938$.

4. Masure, N. P., Bohart, G. S., Eastmond, E. J., and Boggs, M. M., Value of starch coating in the preservation of quality of dehydrated carrots, Food Technol. 4 (3) $94-7,1950$.

5. Cruess, W. V. and Pancoast, H. M., Observations on the oxidase system of the apricot, Univ. Calif. Col. Agr. Expt. Sta., Proj. Rept. 514, 180-201, 1933.

6. Talburt, W. F. and Legult, R. R., Dehydro-frozen peas, Food Technol. 4 (7) 286-91, 1950.

7. Rahman, A. R., The effect of chemical pretreatment on the quality of dehydrated pigeonpeas, J. Agr. Univ. P.R. 45 (3) 172-81, 1961.

8. Lambou, M. G., Sweet potato dehydration: Time and temperature of storage related to organoleptic evaluation, Food Technol. 10 (6) 258-64, 1956.

9. Dutton, H. J., Glen, F. B., and Eleanor, K., Dehydrated spinach: Changes in color and pigments during processing and storage, Ind. \& Eng. Chem. 35 1173-7, 1943.

10. Peryam, D. R. and Pilgrim, F. J., Hedonic scale method of measuring food preferences, Food Technol. 11 (9) 9-14, 1957.

11. Assoc. Off. Agr. Chem., Official Methods of Analysis, Washington, D.C. 8th ed., 1955.

12. Gooding, E. G. B., and Duckworth, R. B., An accelerated storage test for dehydrated vegetables, J. Sci. Food Agr. 8 498-504, 1957. 